\title{
Monday Anxiety in Office Workers
}

Yasin Bez', Abdurrahim Emhan², Mustafa $\mathrm{Arl}^{3}$, Şakir Özen ${ }^{4}$

'Asist. Prof. Dr. ${ }^{4}$ Prof. Dr., Department of Psychiatry, Dicle University Medical School, Diyarbakir - Turkey ${ }^{2}$ Asist. Prof. Dr. Department of Management, Dicle University School of Economics and Administrative Sciences, Diyarbakır - Turkey ${ }^{3}$ Asist. Prof. Dr. Department of Psychiatry, Mustafa Kemal University Medical School, Hatay - Turkey

\section{ABSTRACT}

Monday anxiety in office workers

Objective: In this study, comparison of state and trait anxiety levels of office workers on monday and on thursday was aimed.

Method: On monday morning, sociodemographical form, State Anxiety Inventory (SAI), Trait Anxiety Inventory (TAI) and Beck Depression Inventory (BDI) were delivered to the 230 office workers. The data collected from 144 participants were usable. On thursday morning ( 3 days after) anxiety inventories were delivered again to these 144 workers. Complete and valid forms were collected from 61 participants.

Results: The mean SAl scores of 61 participants on monday and on thursday were $44.4 \pm 10.2$ and $42.2 \pm 9.9$ $(t=2.226, p=0.030)$ respectively; whereas their TAl scores were $44.7 \pm 8.8$ and $43.0 \pm 8.2(t=2.123, p=0.038)$ respectively. Mean BDI scores was 14.4+10.5. Mean TAI scores of workers both on monday and thursday were higher than managers'. Similarly, mean BDI score of workers on Monday was also higher than managers'. Mean TAl scores was higher in middle aged workers than youngs and higher in women than men. Additionally, mean SAl and TAl scores of high school graduates were higher than university graduates'.

Conclusion: Relatively higher levels of anxiety on monday was found to be associated with woman gender, being over middle ages, longer job experience in the same work, lower education level, and being blue collar employee.

Key words: Anxiety, office workers, monday, thursday

\section{ÖZET}

Büro çalışanlarında pazartesi kaygısı

Amaç: Bu araştırmada, büro çalışanlarının pazartesi ve perşembe günlerine ait durumluk ve sürekli kaygı düzeylerinin karşılaştııııması amaçlandı.

Yöntem: Pazartesi sabahı 230 vergi dairesi çalsşanına sosyodemografik bilgi formu, durumluk kaygı envanteri (DKE), sürekli kaygı envanteri (SKE) ve Beck depresyon envanteri (BDE) dağıtııldı. Toplam 144 kişiden güvenilir bilgi elde edildi. Bu 144 kişiye, perşembe sabahı (3 gün sonra) kaygı ölçekleri yeniden dağıtıldı, 61 kişiden güvenilir ve eksiksiz bilgi elde edildi.

Bulgular: 61 kişinin DKE puanı pazartesi sabahı 44.4 \pm 10.2 iken, perşembe sabahı $42.2 \pm 9.9$ olarak bulundu $(t=2.226, p=0.030)$. SKE puanının ise pazartesi günü $44.7 \pm 8.8$, perşembe günü $43.0 \pm 8.2$ olduğu tespit edildi $(t=2.123, p=0.038)$. Pazartesi günkü BDE puanı $14.4 \pm 10.5$ bulundu. Hem pazartesi hem de perşembe günü memurların SKE puanı ortalaması, yöneticilerinkinden daha yüksekti. Benzer şekilde, memurların pazartesi günkü BDE puanları da, yöneticilerinkinden daha yüksekti. SKE puanı ortalamaları pazartesi günü, orta yaştaki memurlarda gençlerden ve kadınlarda erkeklerden daha yüksekti. Ayrıca, lise mezunlarının SKE ve DKE puanlarının üniversite mezunlarınkinden daha yüksek olduğu görüldü.

Sonuç: Pazartesi günü kısmen yüksek olan kaygl; kadın olma, orta yaş üstünde olma, uzun süre aynı işte çallş̧ma, düşük eğitim seviyesi ve yönetilen olma değişkenleri ile ilişkili bulundu.

Anahtar kelimeler: Kaygı, büro çalışanları, pazartesi, perşembe
Address reprint requests to:

Asist. Prof. Dr. Yasin Bez, Department of Psychiatry, Dicle University Medical School, 21280, Diyarbakır - Turkey

Phone: +90-412-248-8001/4817

E-mail address: yasinbez@gmail.com

Date of acceptance: November 11, 2010

\section{INTRODUCTION}

M onday is the first working day of the week in many countries and has a different meaning from other days of the week for employees. "Productivity" is an important concept in working life and while the week proceeds, productivity may decrease due to tiredness. However, in some surveys it was reported that mean working duration per person is lower on Mondays compared to other days of the week. Due to difficulty of adaptation to work after two days of holiday, there is some decrease in productivity on Mondays. Moreover, there is also a decrease in motivation because Monday is the furthest day to the following resting and free time day (1).

There is quite a big amount of people in industrialized countries who see Monday as the worst day of the week 
when mood is considered. For this reason, this condition has been called as "Monday blues" or "Black Monday". Many studies supported this idea and in these studies, heart attack, stroke, suicide, work accidents, absence for work, negative memories and decreased work performance were reported on Mondays when compared to other days of the week (2-9).

Some studies paid attention to first hours of the day and especially 8-9 am of Mondays related with the occurrence of heart attacks and strokes $(10,11)$. Physiological changes and increased autonomic nervous system activity in the morning hours may have a role in heart attack and stroke occurrence in people working daytime in the week. Increase in physical and mental activity needed when passing from freedom state of weekend holiday to Monday which is the first day of planned and stressful activities was also found responsible for heart attack and stroke (3-10).

Emotional component of stress may fluctuate during weekdays (12). For example, Larsen and Kasimatis (11) told about a weekly mood cycle. According to this, mean depression severity is lowest on Friday and Saturday and highest on Monday and Thursday. On the other hand, in some other studies it was proposed that these mood swings are not only observed on Mondays but also between traditional working days and weekends (14).

Emotional fluctuations are directly or indirectly related with the productivity of the worker (1). In a study done in United States, positive feelings were found to be highest in midday and evening and negative feelings were highest in late morning and afternoon (15).

In previous studies, relationship between weekdays and physical disorders and emotional changes were emphasized. However, there is not adequate data in the literature about the changes in anxiety which is one of the main emotional components of stress. In our study, we aimed to determine and compare anxiety levels of office workers on Monday which is the first day of the week and on Thursday which is a midweek day.

\section{METHODS}

\section{Design of the study and participants}

The study was planned in employees of the Tax
Office which is a state office giving a bureau type service. Directors of the Tax Offices of Diyarbakir were visited and required permissions were taken. Start-up date determined for the study was a Monday. Tax Offices were visited and 285 employees who were not under psychiatric treatment were informed about the study. Among them, 230 employees volunteered to participate in the study. Forms and scales were given to volunteers in $8.30 \mathrm{am}$ and told that scales will be re-collected in 90 minutes time. One hundred and sixtyfour employees completed the scales at the end of the period and 144 of them which fulfilled were taken into assessment. Same 144 employees were re-visited and required to complete the State Anxiety Inventory (SAI) and Trait Anxiety Inventory (TAI) again on Thursday of the same week. Some of them refused to re-fill the scales and 73 of them accepted to re-fill and data from 61 of them which were fully completed were assessed.

On Monday, following forms and scales were given to the participants consecutively:

1. Sociodemographic information form: With this form prepared by our team, sociodemographic characteristics such as age, gender, educational level, marital status, years of employment and title were asked.

2. Statet Anxiety Inventory I (STAI-I): This scale was developed by Spielberger (16) to assess current anxiety state and used at several studies. This self-report scale consists of 20 items. In STAI-I, how the subject feels him/herself is assessed. Subject scores emotions and behaviors in the scale as "1-none, 2-some, 3-much, 4-fully" according to prevalence of them. Lowest score is 20 and highest score is 80 (17).

3. Trait Anxiety Inventory II (STAI-II): This scale was developed by Spielberger (16) to assess continuous anxiety. This self-report scale consists of 20 items and how the subject generally feels him/herself is assessed. Subject scores emotions and behaviors in the scale as "1-nearly never, 2-sometimes, 3-often, 4-nearly always" according to the prevalence of them. Lowest score is 20 and highest score is 80 . Subjects scoring 41 and higher are indicated as anxious for both STAI-I and II. STAI-I and II were translated to Turkish by Öner and Le Compte (17) and they published a handbook containing psychometric properties of them. 
4. Beck Depression Inventory (BDI): BDI is a self-reporting inventory which is widely used in clinics. Twenty-one items of the scale contain a series of expressions in order. Subjects are required to take last 7 days into consideration and choose the most appropriate of these expressions for them. Each expression is scored between $0-3$ and severity of depression is derived by the sum of scores of answers given to each question. Total score varies between 0 and 63. Cut-off point score reported for depression surveys was 17 . Items were prepared according to clinical observations and data. It was first developed by Beck in 1961 (18).

\section{Statistical Methods}

Obtained data were analyzed by SPSS 15.0 version. Student's t-test was used to compare SAI, TAI and age between Monday and Thursday. Mann Whitney U test was used when comparing subjects having work experience less and more than 5 years and subjects under or over 31 years of age. ANOVA test was used when comparison of more than two groups (age distribution, educational level and work experience groups) were needed. Data from 61 subjects who accurately filled both SAI and TAI on both Monday and Thursday were compared by paired t-test. Statistical significance was taken as $\mathrm{p}<0.05$.

\section{RESULTS}

Out of 230 forms distributed to office workers on Monday, 164 (71\%) were returned back and 144 of them $(63 \%)$ were suitable for assessment. On the other hand, 73 employees (51\%) answered the forms distributed on Thursday. Sociodemographic variables of 61 employees (27\%) who fully answered the forms distributed both on Monday and Thursday are shown in Table 1.

When 144 forms distributed on Monday which are suitable for assessment were evaluated, SAI and TAI levelswere found $44.7 \pm 10.1$ and $45.2 \pm 8.4$, consecutively. Mean depression level of the same group on BDI was 14.4 \pm 10.5 . State and trait anxiety levels of 61 subjects whom fulfilled the forms given both on Monday and

Table 1: SAI, TAI and BDI mean scores of participants according to sociodemographic variable sub-groups ( $\mathrm{n}=144)$.

\begin{tabular}{|c|c|c|c|c|}
\hline Demographic Variables & Frequency (\%) & SAI $($ Mean \pm SD $)$ & TAI (Mean \pm SD) & BDI $($ Mean $\pm S D)$ \\
\hline \multicolumn{5}{|l|}{ Gender } \\
\hline Men & $94(\% 34.7)$ & $44.1 \pm 10.2$ & $44.1 \pm 7.6$ & $14.6 \pm 10.9$ \\
\hline Women & $50(\% 65.3)$ & $45.7 \pm 9.9$ & $47.2 \pm 9.4$ & $14.2 \pm 9.7$ \\
\hline \multicolumn{5}{|l|}{ Marital status } \\
\hline Married & $120(\% 83.3)$ & $45.0 \pm 10.0$ & $45.7 \pm 8.2$ & $14.9 \pm 10.7$ \\
\hline Single & $24(\% 16.7)$ & $43.0 \pm 10.2$ & $42.7 \pm 8.8$ & $11.9 \pm 8.7$ \\
\hline \multicolumn{5}{|l|}{ Age } \\
\hline $20-30$ & $16(\% 11.1)$ & $40.2 \pm 10.8$ & $39.2 \pm 10.3$ & $11.6 \pm 9.6$ \\
\hline $31-40$ & $64(\% 44.4)$ & $44.9 \pm 10.3$ & $45.1 \pm 8.3$ & $12.6 \pm 9.6$ \\
\hline $41-50$ & $19(\% 31.3)$ & $46.8 \pm 9.8$ & $47.3 \pm 7.0$ & $15.8 \pm 10.2$ \\
\hline Over 50 & $144(\% 13.2)$ & $42.4 \pm 8.1$ & $45.7 \pm 8.0$ & $19.9 \pm 12.6$ \\
\hline \multicolumn{5}{|l|}{ Educational level } \\
\hline High school & $48(\% 33.3)$ & $47.0 \pm 10.4$ & $47.9 \pm 8.4$ & $18.8 \pm 10.9$ \\
\hline Undergraduate & $89(\% 61.8)$ & $43.4 \pm 10.0$ & $43.4 \pm 8.0$ & $12.4 \pm 9.8$ \\
\hline Graduate & $7(\% 7.9)$ & $44.9 \pm 6.1$ & $48.9 \pm 7.7$ & $11.6 \pm 7.3$ \\
\hline \multicolumn{5}{|l|}{ Title } \\
\hline Manager & $19(\% 13.2)$ & $43.2 \pm 9.7$ & $39.4 \pm 8.2$ & $10.2 \pm 10.6$ \\
\hline Employee & $86(\% 59.7)$ & $44.8 \pm 9.2$ & $46.3 \pm 8.2$ & $15.3 \pm 10.0$ \\
\hline Other & $39(\% 27.1)$ & $45.2 \pm 12.1$ & $44.6 \pm 8.3$ & $14.5 \pm 11.4$ \\
\hline \multicolumn{5}{|l|}{ Work experience (year) } \\
\hline $1-5$ & $12(8.3)$ & $41.3 \pm 9.9$ & $39.9 \pm 7.7$ & $9.6 \pm 7.1$ \\
\hline $6-10$ & 17 (\%11.8) & $43.6 \pm 10.2$ & $41.8 \pm 8.3$ & $12.8 \pm 10.2$ \\
\hline $11-15$ & $36(\% 25)$ & $44.7 \pm 10.4$ & $44.8 \pm 9.0$ & $13.0 \pm 9.7$ \\
\hline $16-20$ & $16(\% 11.1)$ & $44.1 \pm 11.2$ & $44.5 \pm 8.5$ & $15.4 \pm 11.1$ \\
\hline Over 20 & $63(\% 43.8)$ & $45.7 \pm 9.7$ & $47.5 \pm 7.5$ & $16.4 \pm 11.1$ \\
\hline
\end{tabular}

SAI: State anxiety inventory; TAI: Trait anxiety inventory; BDI: Beck depression inventory; SD: Standard deviation. 
Table 2: Comparison of the state and trait anxiety levels between Monday and Thursday with paired t-test.

\begin{tabular}{|c|c|c|c|c|c|c|}
\hline Variables & Days & $\mathbf{n}$ & Mean & SD* $^{*}$ & $\mathbf{t}^{* *}$ & $\mathbf{p}$ \\
\hline \multirow[t]{2}{*}{ State Anxiety Inventory } & Monday & 61 & 44.4 & 10.2 & 2.226 & 0.030 \\
\hline & Thursday & 61 & 42.2 & 9.9 & & \\
\hline \multirow{2}{*}{ Trait Anxiety Inventory } & Monday & 61 & 44.7 & 8.8 & 2.123 & 0.038 \\
\hline & Thursday & 61 & 43.0 & 8.2 & & \\
\hline
\end{tabular}

*SD: Standard deviation, ${ }^{* *}$ t: Paired t test

Thursday are shown in Table 2.

State and trait anxiety levels of 144 subjects of Monday were evaluated according to age, gender, work experience and educational level. When compared by ANOVA test, Monday TAI scores of subjects at second decade were lower than all groups over 30 years of age in Table 1 ( $F=3.985, p=0.009)$. Consistent with this finding, subjects having less than 5 years of work experience obtained lower TAI scores than subjects having 20 years or more work experience $(z=2.979$, $p=0.003)$. When data were compared according to gender, Monday TAI scores were found higher in women ( $t=2.113, p=0.036$ ). SAI and TAI scores were higher in high school graduates than university graduates $(t=2.011, p=0.046$ and $t=3.089, p=0.002$, consecutively). No difference was found when marital status was considered.

TAI scores of employees on Monday and Thursday were higher than their managers $(t=2.269, p=0.023$ and $t=2.158, p=0.03$, consecutively). Similarly, BDI scores of employees were also higher than their managers $(\mathrm{t}=2.035, \mathrm{p}=0.042)$.

Sixty-one subjects who fulfilled the scales on Monday and Thursday were separately evaluated. SAI and TAI scores of this group on Monday were $44.4 \pm 10.2$ and $44.7 \pm 8.8$ and on Thursday $42.2 \pm 9.9$ and $43.0 \pm 8.2$, consecutively. State and trait anxiety levels on Monday were statistically significantly higher than levels found on Thursday (for SAI $t=2.226$, $p=0.030$ and for TAI $t=2.123, p=0.038)$. Anxiety level differences of different weekdays and statistical analyses are shown in Table 2.

\section{DISCUSSION}

Response rates of the participants were $71 \%$ on Monday and $51 \%$ on Thursday. This means that volunteering to fill the questionnaire was decreased. Although the reasons of this decrease were not investigated in our study, authors have got the impression that subjects who did not answer on Thursday did so because they already answered on Monday. Twenty-five percent of subjects who accepted to participate to the study in the beginning delivered full and usable data at the end of the study.

Mean anxiety scores of the participants on Monday were around 45 and this showed that employees had mild anxiety. Mean BDI scores were under 17 so it can be said that most of the employees working at that office were not under risk of depression.

Trait anxiety levels of office workers at third and fourth decades and over 50 years of age on Monday were found higher than office workers at second decade. Trait anxiety levels of employees having longer work experience and lower educational level were higher. It can be proposed that these employees reached at a plateau in their careers and have a lower chance of promotion and for this reason have a higher level of anxiety $(20,21)$.

Trait anxiety scores of employees were higher than managers. Although this finding had a borderline statistical significance, it is in accordance with the data from literature which showed that employees experience more psychological problems than managers (22). Assessment of women in our study group on Monday showed higher trait anxiety levels than men and this is also similar with the findings in the literature that some psychopathological findings including anxiety disorders are seen more in women $(23,24)$.

When 61 subjects who gave full information on both days were evaluated, higher state and trait anxiety levels found on Monday than on Thursday confirms the main hypothesis of our study. Although clinical significance of the differences of SAI and TAI scores 
between two days are debatable, in some clinical studies done in other countries reported that Monday is also related with fatigue and blues (8).

A general conclusion which is clinically important is the higher prevalence of physical diseases such as heart attack, stroke and arrhythmias which are closely related with stress on Mondays (2-4). Physical diseases of the participants or their ex-colleagues which occurred on Mondays were not asked in our study. Some authors related physical diseases occurred on Monday with cultural differences in eating habits which may vary on different days of the week $(4,10,25)$. Weekly holidays may vary in different societies so it should be kept in mind that importance of Monday is due to its being the first day of the week $(1,26)$. When obtained data is generally looked over, it may be useful to distribute the workload to the weekdays other than Monday when weekly work plan is being prepared.

Authors are aware of some of the limitations of this study. The most important limitation of this study is the absence of a control group which is not working on a 9-to-5 schedule. Moreover, low rate of completers on Thursday makes it difficult to generalize our findings to all office workers. Another limitation was the comparison of only two days of the week. Not detecting the morningness or eveningness nature of the participants was also another limitation. Variables such as weather conditions, physical characteristics of working conditions and seasonal differences which all may vary between working days were not controlled in our study.

In conclusion, office workers experience higher levels of anxiety on Monday compared to Thursday. Partially higher anxiety levels on Monday seem to be related with advanced age, longer work experience (working in the same job for a longer period of time), lower educational level, female gender and employee status. In order to increase our knowledge about the psychological effects of weekdays on employees, further researches are required to investigate all weekdays and other jobs as well.

\section{REFERENCES}

1. Bryson A, Forth J. Are there day of the week productivity effects? Manpower Human Resources Lab, London School of Economics, Discussion Paper 2007, No.4.

2. Sari I, Erer B, Tekbas E, Ucer E, Uyarel H, Davutoglu V, Ozer O, Sucu M, Soydinc S, Aksoy M. Septadian variation in the occurrence of ST elevation myocardial infarction in Turkish population: Monday syndrome. Circulation 2008; 118:162-413.

3. Willich SN, Lowel H, Lewis M, Hormann A, Arntz HR, Keil $\mathrm{U}$. Weekly variation of acute myocardial infarction. increased Monday risk in the working population. Circulation 1994; 90:8793.

4. Evans CJ, Chalmers JWT, Capewell S, Redpath A, Finlayson AR, Boyd JH, Pell JP, McMurray JV, Macintyre K, Graham L. "I don't like Mondays" - day of the week of coronary heart disease deaths in Scotland: study of routinely collected data. BMJ 2000; 320:218-219.

\section{rosses}

5. Maldonado G, Kraus JF. Variation in suicide occurrence by time of day, day of the week, month, and lunar phase. Suicide Life Threat Behav 1991; 21:174-187.

6. Campolieti M, Hyatt DE. Further evidence on the 'monday effect' in workers' compensation. Ind Labor Relat Rev 2006; 59:438-450

7. Muchinsky PM. Employee absenteeism: A review of the literature. J Vocat Behav 1977; 10:316-340.

\section{Crosiref}

8. Koeske GF, Kirk SA, Koeske RD, Rauktis MB. Measuring the Monday blues: Validation of a job satisfaction scale for the human services. Soc Work Res 1994; 18:27-35.

9. Areni CS, Burger M. Memories of "bad" days are more biased than memories of "good" days: past saturdays vary, but past mondays are always blue. J Appl Soc Psychol 2008; 38:13951415.

\section{Crosser}

10. Oren H, Cosgun A. Weekly Variation of the OT Dispersion in Healthy Subjects and in Patients with Coronary Heart Disease. Cardiology 2007; 108:55-61.

\section{crossef}

11. Larsen RJ, Kasimatis M. Individual differences in entrainment of mood to the weekly calendar. J Pers Soc Psychol 1990; 58:164171.

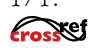


12. Akay A, Martinsson P. Sundays are blue: aren't they? -the dayof-the-week effect on subjective well-being and socio-economic status. Working papers in economics 2009, No: 397.

13. Reinhold BB. Toxic Work: How to overcome stress, overload, and burnout and revitalize your career. New York, NY: Dutton Publication, 1996.

14. Croft GP, Walker AE. Are the Monday blues all in the mind? The role of expectancy in the subjective experience of mood. J Appl Soc Psychol 2001; 31:1133-1145.

\section{irosuef}

15. Stone AA, Schwartz JE, Schkade D, Schwarz N, Krueger A, Kahneman DA. Population approach to the study of emotion: Diurnal rhythms of a working day examined with the day reconstruction method. Emotion 2006; 6:139-149.

\section{Croster}

16. Spilberger CD, Gorsuch RL, Lushene RD. Manual for the statetrait anxiety inventory. Palo Alto, CA: Consulting Psychologist Press, 1970.

17. Öner N, Compte AL. Süreksiz durumluk / Sürekli Kayg1 Envanteri El kitabı. 2. Basım, Boğaziçi Üniversitesi Yayınevi, İstanbul, 1998. (Book in Turkish)

18. Beck AT, Ward CH, Mendelson M, Mock J, Erbaugh J. An inventory for measuring depression. Arch Gen Psychiatry 1961; 4:561-71.
19. Hisli N. Beck depresyon envanterinin üniversite öğrencileri için geçerlilik ve güvenirliliği. Psikoloji Dergisi 1989; 7:3-13 (Article in Turkish)

20. Daft RL. Management. New York, NY: The Dryden Press, 1991.

21. Ference TP, Stoner JA, Warren EK. Managing the career plateau. Acad Manage Rev 1977; 2:602-612

\section{Crossef}

22. Myrtek M, Fichtler A, Strittmatter M, Brügner G. Stress and strain of blue and white collar workers during work and leisure time: results of psychophysiological and behavioral monitoring. Appl Ergon 1999; 30:341-351.

\section{Crossef}

23. Gove WR. Sex differences in mental illness among adult men and women: An evaluation of four questions raised regarding the evidence on the higher rates of women. Soc Sci Med 1978; 12:187-198.

24. Rossi AS, Rossi PE. Body time and social time: Mood patterns by menstrual cycle phase and day of the week. Soc Sci Res 1997; 6:273-308.

\section{crossef}

25. Diener E, Oishi S, Lucas RE. Personality, culture, and subjective well-being: emotional and cognitive evaluations of life. Annu Rev Psychol 2003; 54:403-425.

\section{Crosser}

26. Anson J, Anson O. 'Thank God it's Friday: the weekly cycle of mortality in Israel. Popul Res Policy Rev 2000; 19:143-154

\section{erosser}

